\title{
Spanish Version of the Teachers' Sense of Efficacy Scale: An Adaptation and Validation Study
}

\author{
Fátima Salas-Rodríguez ${ }^{1 *}$, Sonia Lara ${ }^{1}$ and Martín Martínez² \\ ${ }^{1}$ Department of Learning and Curriculum, University of Navarra, Pamplona, Spain, ${ }^{2}$ Cognitive and Affective Methods \\ in Psychology, Department of Research Theory and Methods in Education and Psychology, University of Navarra, Pamplona, \\ Spain
}

The Teachers' Sense of Efficacy Scale (TSES) has been the most widely used instrument to assess teacher efficacy beliefs. However, no study has been carried out concerning the TSES psychometric properties with teachers in Mexico, the country with the highest number of Spanish-speakers worldwide. The purpose of the present study is to examine the reliability, internal and external validity evidence of the TSES (short form) adapted into

OPEN ACCESS

Edited by:

Ghaleb Hamad Alnahdi, Prince Sattam Bin Abdulaziz

University, Saudi Arabia

Reviewed by:

Angelica Moè,

University of Padua, Italy

Jalil Fathi,

University of Kurdistan, Iran

Ann-Katrin Van Den Ham,

University of Hamburg, Germany

Jiahong Zhang,

University of Wisconsin-Madison,

United States

*Correspondence:

Fátima Salas-Rodríguez fsalas@alumni.unav.es

Specialty section:

This article was submitted to Educational Psychology, a section of the journal Frontiers in Psychology

Received: 24 May 2021 Accepted: 08 October 2021 Published: 11 November 2021

Citation:

Salas-Rodríguez F, Lara S and Martínez M (2021) Spanish Version of the Teachers' Sense of Efficacy

Scale: An Adaptation and Validation Study. Front. Psychol. 12:714145 doi: 10.3389/fpsyg.2021.714145
Spanish with a sample of 190 primary and secondary Mexican teachers from 25 private schools. Results of construct analysis confirm the three-factor-correlated structure of the original scale. Criterion validity evidence was established between self-efficacy and job satisfaction. Differences in self-efficacy were related to teachers' gender, years of experience and grade level taught. Some limitations are discussed, and future research directions are recommended.

Keywords: Teachers' Sense of Efficacy Scale, construct validity, criterion validity, self-efficacy, job satisfaction, Mexico

\section{INTRODUCTION}

Teacher self-efficacy is critical to the creation of effective teaching and learning environments. At first, the interest in this variable was due to the relationship found between teacher efficacy beliefs, motivation, and academic improvement of their students (Armor et al., 1976; Berman et al., 1977). However, in recent years, teacher self-efficacy has taken on special importance due to its relationship with teachers' well-being. Previous studies have found that teachers with high levels of self-efficacy tend to have higher levels of job satisfaction (Caprara et al., 2006; Skaalvik and Skaalvik, 2010; Vieluf et al., 2013; Malinen and Savolainen, 2016; Burić and Kim, 2021), lower levels of stress (Klassen and Chiu, 2010; Zee and Koomen, 2016; Skaalvik and Skaalvik, 2017; Fathi et al., 2021), and less desire to leave the profession (Chesnut and Burley, 2015; Wang et al., 2015; Skaalvik and Skaalvik, 2016).

Studies such as those of Klassen et al. (2009), Ruan et al. (2015), and Fackler (2018) have demonstrated that teacher self-efficacy is a valid construct in different cultural contexts. Nonetheless, there is a lack of research on this subject in Spanish-speaking countries. Casas Moreno and Blanco-Blanco (2016) asserts that the scarcity of studies in these countries may be due to a lack of psychometric tools that allow a valid and reliable assessment of teachers' efficacy beliefs.

Abbreviations: TSES, Teachers' Sense of Efficacy Scale; IS, instructional strategies; CM, classroom management; SE, student engagement; CFA, confirmatory factor analysis; JSC, job satisfaction composite scale; JSWE, job satisfaction with work environment; JSP, job satisfaction with profession. 
This research seeks to promote the study of self-efficacy in Spanish-speaking contexts by adapting the Teachers' Sense of Efficacy Scale (TSES; Tschannen-Moran and Woolfolk Hoy, 2001) into Spanish and studying its psychometric properties with a sample of Mexican teachers.

\section{Teachers' Self-Efficacy: Its Meaning and Measurement}

Framed in Bandura's social cognitive theory, teacher self-efficacy is defined as "the teacher's belief in his or her capability to organize and execute courses of action required to successfully accomplish a specific teaching task in a particular context" (Tschannen-Moran et al., 1998, p. 233). Teachers with high levels of self-efficacy beliefs are distinguished by having a greater commitment to the teaching profession and its students (Chesnut and Burley, 2015); showing greater openness to change and innovation (Bandura, 1997; Tsigilis et al., 2007); spending more time teaching in class (Organization for Economic Co-operation and Development [OECD], 2019a); having a more positive affect (Burić and Moè, 2020); presenting greater levels of instructional quality (Künsting et al., 2016; Burić and Kim, 2020); tending to collaborate to a greater extent with other teachers (Skaalvik and Skaalvik, 2010); and establishing closer relationships with their students (Zee and Koomen, 2017; Hajovsky et al., 2020; Wettstein et al., 2021).

Although teacher self-efficacy has always been related to educational improvement, one of the problems in the study of these beliefs has been reaching a consensus regarding the conceptualization and evaluation of this construct (Skaalvik and Skaalvik, 2007). To address this, Tschannen-Moran et al. (1998) conducted a review of the theoretical and empirical foundations of teacher self-efficacy and proposed an integrated model based on the idea that in order to properly asses teachers' self-efficacy beliefs, two factors need to be known: the assessment of one's own competence and the analysis of the teaching task. Essentially, teachers develop their self-efficacy beliefs based on the assessment of their own competence with respect to the perceived demands of the teaching task at hand (Tschannen-Moran et al., 1998). In this way, teachers anticipate the difficulty of the task and assess the resources at their disposal by analyzing the contextual factors that favor or hinder teaching performance. Perception of one's own teaching competence is related to the tasks to be fulfilled, i.e., how capable I am to achieve a certain performance with respect to a particular task.

This integrated model became the basis for the TSES (Tschannen-Moran and Woolfolk Hoy, 2001). The TSES measures teacher self-efficacy using 24 items in its long form or 12 items in its short form. Items are grouped into three different but inter-correlated factors: efficacy for instructional strategies, efficacy for classroom management, and efficacy for student engagement. These three factors reflect the multi-faceted nature of self-efficacy both by presenting a wide variety of teaching tasks and maintaining a balance between the general and the specific, which allows the scale to be used in different contexts and at different educational levels. Items focus on assessing teachers' judgment of their own capability by including the stem, "How much can you do to..." or "To what extent can you..." and are measured following a nine-point Likert scale.

Evidence on the TSES was first validated with a convenience sample of 255 in-service and 103 pre-service teachers from the United States. After using principal-axis factoring with Varimax rotation, a three-factor structure was found for the in-service teachers, and a single factor was recommended for the preservice teachers. Thanks to its solid theoretical foundation and its stable factor structure, the TSES has been by far the most widely used scale for assessing teachers' self-efficacy beliefs (Woolfolk Hoy and Spero, 2005). Multiple studies have adapted and evaluated validity evidence of the scale with in-service and pre-service teachers of different countries and languages; Table 1 presents some of these studies. As a result, a more comprehensive understanding of the construct and the TSES has been obtained.

\section{Teachers' Sense of Efficacy Scale From an International Perspective}

Regarding the psychometric properties of the TSES, prior investigations suggest the scale has been characterized by strong levels of reliability across diverse cultural contexts (Klassen et al., 2009; Ruan et al., 2015). Construct validity evidence has been mainly studied through confirmatory factor analysis (CFA), and the three correlated factor structure proposed by TschannenMoran and Woolfolk Hoy (2001) has been supported by several studies (see Table 1). However, in order to improve the goodnessof-fit of the three-factor model, certain studies have allowed some items' errors to correlate (Klassen et al., 2009; Ninković and Knežević-Florić, 2018) or have removed items with low loadings or cross-loaded with other factors (Tsigilis et al., 2010; Ruan et al., 2015; Khairani and Makara, 2020).

Regarding criterion validity evidence, teacher self-efficacy, as measured by the TSES, has been previously related to job satisfaction (Klassen et al., 2009; Tsigilis et al., 2010; Ninković and Knežević-Florić, 2018), being a main determinant of this variable and influencing teachers' attitudes and performance (Caprara et al., 2003). Specifically, teachers with high levels of self-efficacy tend to demonstrate higher levels of job satisfaction (Caprara et al., 2006; Klassen and Chiu, 2010; Vieluf et al., 2013).

In the Latin American context, the psychometric properties of the TSES have been less studied, and the few existing studies present mixed results. For instance, with a sample of inservice Chilean teachers, Covarrubias Apablaza and Mendoza Lira (2016) reduced the scale from 24 to 17 items and grouped them by four different factors: the three original factors and a new one named efficacy in attending to the uniqueness of students. On the other hand, Dominguez-Lara et al. (2019) used the TSES (long version) with a sample of in-service Peruvian teachers and found that the one-factor model adjusted better to the collected data. Further studies are needed in order to ascertain how the TSES behaves in the Latin American context.

According to previous cross-cultural studies, teacher selfefficacy has a similar meaning in different countries (Vieluf et al., 2013; Ruan et al., 2015; Fackler and Malmberg, 2016). Nonetheless, self-efficacy beliefs have been known to be 
TABLE 1 | Psychometric studies of the TSES around the world.

\begin{tabular}{|c|c|c|c|c|c|c|c|}
\hline Article & Sampling & Participants & Country & Scale form & Analyses & Proposed model & Fit statistics \\
\hline $\begin{array}{l}\text { Burgueño et al., } \\
2019\end{array}$ & Convenience & $\begin{array}{l}358 \text { pre-service } \\
\text { teachers }\end{array}$ & Spain & $\begin{array}{l}24,12 \text {, and } 11 \\
\text { items; } 1-9 \text { Likert } \\
\text { scale }\end{array}$ & CFA & $\begin{array}{l}\text { Modified } \\
\text { three-factor-correlated } \\
\text { model for the } 11 \text { items } \\
\text { scale form }\end{array}$ & $\begin{array}{l}\chi^{2} / d f=1.7 \\
C F I=0.979 \\
\text { TLI = 0.972; } \\
\text { SRMR =0.031; } \\
\text { RMSEA = 0.052 }\end{array}$ \\
\hline Çapa et al., 2005 & Convenience & $\begin{array}{l}628 \text { pre-service } \\
\text { teachers }\end{array}$ & Turkey & $\begin{array}{l}24 \text { items; } 1-9 \\
\text { Likert scale }\end{array}$ & CFA & $\begin{array}{l}\text { Three-factor-correlated } \\
\text { model for the } 24 \text { items } \\
\text { scale form }\end{array}$ & $\begin{array}{l}\mathrm{CFI}=0.99 ; \mathrm{TLI}=0.99 \\
\mathrm{RMSEA}=0.065\end{array}$ \\
\hline $\begin{array}{l}\text { Covarrubias } \\
\text { Apablaza and } \\
\text { Mendoza Lira, } \\
2016\end{array}$ & Convenience & $\begin{array}{l}544 \text { teachers: } \\
\text { kindergarten (9.2\%), } \\
\text { primary }(52.2 \%), \\
\text { secondary }(38.6 \%)\end{array}$ & Chile & $\begin{array}{l}24 \text { items; } 1-5 \\
\text { Likert scale }\end{array}$ & EFA/CFA & $\begin{array}{l}\text { Four-factor model for the } \\
17 \text { items scale form }\end{array}$ & $\begin{array}{l}x^{2} / d f=1.36 \\
C F I=0.959 ; \\
I F I=0.96 ; \\
\text { SRMR =0.05; } \\
\text { RMSEA = 0.054 }\end{array}$ \\
\hline $\begin{array}{l}\text { Dominguez-Lara } \\
\text { et al., } 2019\end{array}$ & NS & 347 in-service teachers & Peru & $\begin{array}{l}24 \text { items; } 1-5 \\
\text { Likert scale }\end{array}$ & CFA/ESEM & $\begin{array}{l}\text { One-factor model for the } \\
24 \text { items scale form }\end{array}$ & $\begin{array}{l}\mathrm{CFI}=0.949 \\
\mathrm{RMSEA}=0.065\end{array}$ \\
\hline Htang, 2018 & Convenience & $\begin{array}{l}101 \text { pre-service } \\
\text { teachers }\end{array}$ & Myanmar & $\begin{array}{l}12 \text { items; } 1-5 \\
\text { Likert scale }\end{array}$ & EFA/CFA & $\begin{array}{l}\text { Three-factor-correlated } \\
\text { model for the } 12 \text { items } \\
\text { scale form }\end{array}$ & $\begin{array}{l}x^{2} / d f=1.36 \\
C F I=0.966 \\
I F I=0.967 \\
\text { SRMR = } \\
\text { RMSEA = } 0.054\end{array}$ \\
\hline $\begin{array}{l}\text { Khairani and } \\
\text { Makara, } 2020\end{array}$ & Purposive & $\begin{array}{l}122 \text { pre-service } \\
\text { teachers and } 191 \\
\text { secondary teachers }\end{array}$ & Malaysia & $\begin{array}{l}24 \text { items; } 1-5 \\
\text { Likert scale }\end{array}$ & CFA & $\begin{array}{l}\text { Modified } \\
\text { three-factor-correlated } \\
\text { model for the } 21 \text { items } \\
\text { scale form }\end{array}$ & $\begin{array}{l}x^{2} / d f=2.35 \\
C F I=0.883 \\
\text { TLI = 0.87; } \\
\text { SRMR =0.054; } \\
\text { RMSEA =0.066 }\end{array}$ \\
\hline $\begin{array}{l}\text { Tsigilis et al., } \\
2010\end{array}$ & Convenience & $\begin{array}{l}405 \text { primary and } \\
\text { secondary teachers }\end{array}$ & Greece & $\begin{array}{l}24 \text { items; } 1-9 \\
\text { Likert scale }\end{array}$ & CFA & $\begin{array}{l}\text { Three-factor-correlated } \\
\text { model for the } 24 \text { items } \\
\text { scale form }\end{array}$ & $\begin{array}{l}\chi^{2} / d f=4.06 \\
C F I=0.893 \\
\text { SRMR = 0.058; } \\
\text { RMSEA = 0.088 }\end{array}$ \\
\hline Valls et al., 2020 & NS & $\begin{array}{l}283 \text { teachers: primary } \\
(59.7 \%) \text {, secondary } \\
(35 \%) \text {, combined } \\
(5.3 \%)\end{array}$ & Switzerland & $\begin{array}{l}12 \text { items; } 1-9 \\
\text { Likert scale }\end{array}$ & CFA & $\begin{array}{l}\text { Three-factor-correlated } \\
\text { model for the } 12 \text { items } \\
\text { scale form }\end{array}$ & $\begin{array}{l}\chi^{2} / d f=3.63 ; \\
\mathrm{CFI}=0.90 ; \text { TLI }=0.87 ; \\
\mathrm{SRMR}=0.061 ; \\
\mathrm{RMSEA}=0.097\end{array}$ \\
\hline
\end{tabular}

CFA, confirmatory factor analysis; EFA, exploratory factor analysis; ESEM, exploratory structural equation modeling; NS, not specified; RMSEA, root mean square error of approximation; SRMR, standardized root mean square residual; CFI, comparative fit index; TLI, Tucker-Lewis index.

context-dependent and may vary according to cultural values and teacher demographic variables such as gender, teaching field, and teaching experience (Dilekli and Tezci, 2020). Therefore, it is necessary to take into account the characteristics of the sample while studying teacher self-efficacy to better understand the results obtained in the Latin American context.

\section{Present Study}

The overall purpose of this study is to obtain internal and external validity evidence supporting the use of the Teacher's Sense of
Self-Efficacy Scale (TSES, Tschannen-Moran and Woolfolk Hoy, 2001) in Spanish speakers while it is tested on a sample of private school teachers in Mexico. To achieve this purpose, we set out to determine if the three-dimensional factor-analytic solution presented by the original short form of the TSES is replicated in a sample of Mexican teachers, and the extent to which the TSES subscales are related in theoretically meaningful ways to subscales of job satisfaction and other demographic variables such as teacher's gender, subject taught, school level, teaching experience, and school model. Internal validity evidence 
will support that Mexican teachers develop capabilities on instructional strategies, classroom management, and student engagement; that the content domain of the test is consistent with self-efficacy perception; that test scores can be generalized across sets of items; that the level of self-efficacy in Mexican teachers can be validly assessed; and that teachers with high scores on the test will have a higher perception of self-efficacy than teachers with low scores.

Criterion validity evidence will support that teachers' selfefficacy beliefs will be significantly and directly associated with job satisfaction in this sample. In this regard, previous studies have found weak correlations between these two variables. For example, Ninković and Knežević-Florić (2018) found that job satisfaction correlated with each subscale of the TSES $r_{I S}=0.40$, $\mathrm{r}_{S E}=0.46, \mathrm{r}_{C M}=0.38$. Similarly, Klassen et al. (2009) found these significant correlations in teachers from Canada, Cyprus, South Korea, and the United States, ranging from 0.17 to 0.48 .

Regarding teachers' demographic variables, previous studies have shown that variables such as gender, school grade, and teaching experience predict teachers' self-efficacy (Klassen and Chiu, 2010; Perera et al., 2019). While studies on the differences in teacher self-efficacy according to teacher gender have yielded inconsistent results, it is expected that female and male teachers present different levels of self-efficacy (Lumpe et al., 2012; Perera et al., 2019). In accordance with school grade, the literature has shown that primary school teachers tend to have higher levels of self-efficacy than secondary teachers (Fives and Buehl, 2009). Finally, teacher's self-efficacy has shown a non-linear relationship with teaching experience (Klassen and Chiu, 2010); in which selfefficacy increases from 0 to about 20 years of experience and then declines as years of experience increase.

Our hypotheses are as follows:

H1. The TSES Spanish version will have the same factor structure as the original scale for in-service teachers (Tschannen-Moran and Woolfolk Hoy, 2001): three correlated factors-Instructional strategies, Classroom management, Student engagement-with four items each. Internal validity evidence will be examined by conducting a CFA to analyze whether the items load on their original factor.

H2. Teacher self-efficacy will present a positive and significant weak correlation with teachers' job satisfaction, as observed in multiple studies (Caprara et al., 2003; Klassen et al., 2009; Skaalvik and Skaalvik, 2010; Tsigilis et al., 2010; Vieluf et al., 2013; Ninković and Knežević-Florić, 2018). Therefore, we expect to find significant correlation between both scales -TSES and JSC- and their factors. This hypothesized correlation will provide external validity evidence to the TSES scale in the Mexican sample.

H3. Considering previous studies, teacher self-efficacy and its factors will present significant differences regarding demographic variables.

H3.1 Teachers' levels of self-efficacy will differ significantly according to gender.
H3.2 Primary school teachers will have higher levels of selfefficacy than secondary school teachers.

H3.3 Years of experience will affect self-efficacy of teachers; selfefficacy will increase during the first years of the career but will decrease during later stages.

Testing these hypotheses will help us understand how teacher self-efficacy behaves within the Mexican sample, shedding light on possible avenues of action.

\section{MATERIALS AND METHODS}

\section{Participants and Procedure}

The convenience sample for this study consisted of 190 in-service teachers (120 females, 70 males; $M_{\text {age }}=40.89, S D=10.05$ ) from 25 private schools in Mexico. Among the teachers from whom the data were collected, $47.9 \%$ taught Spanish and 52.1\% taught mathematics, to students in 4 th grade $(n=45)$, 5 th grade $(n=39)$, 6 th grade $(n=34), 7$ th grade $(n=34)$, and 8 th grade $(n=38)$. Years of teaching experience ranged from 1 to 41 , with a mean of 16 years $(S D=9.98)$.

It is important to underline why we selected in-service teachers from private schools in Mexico. As shown in Table 1, the TSES has been mostly adapted and validated with primary and secondary teachers. However, in the Mexican context, public schools are not K-12, being private schools the only way to compare self-efficacy beliefs within teachers from the same school but different educational levels.

Data were collected at the end of the 2019-2020 academic year using a Google Forms questionnaire. Participants were aware of the purpose of the study and completed the questionnaire anonymously. Ethical approval was obtained by the Research Ethics Committee of the authors' affiliated university (Project ID: 2020.042).

\section{Instrumentation}

Teacher self-efficacy was measured using the TSES short form (Tschannen-Moran and Woolfolk Hoy, 2001) with the permission of one of the authors of the scale (MTM). This instrument comprises 12 items grouped into three subscales: Efficacy for instructional strategies (IS; four items), Efficacy for classroom management (CM; four items), and Efficacy for student engagement (SE; four items). Items were measured following a nine-point Likert scale, ranging from 1 (nothing) to 9 (a great deal), and the global score of the TSES was obtained by averaging the mean score of the three factors. The overall reliability of the original scale was good $(\alpha=0.90)$, as was the consistency of its subscales, with values ranging from 0.81 to 0.86 .

The Spanish version of the TSES was established using the translation and back-translation procedure. First, a native Spanish-speaking scholar translated the TSES into Spanish. Second, a native English professional re-translated the scale from Spanish to English. Third, the authors and the professionals reviewed both versions item by item in order to detect semantic and/or conceptual differences between the original and translated versions. Any differences were discussed, and a consensus 
was reached for each item. Finally, a Mexican scholar and two Mexican education professionals revised the TSES Spanish version to ensure the neutrality of the vocabulary used in the adaptation. It was concluded that no further changes were necessary due to the standard register of the language used in the scale. Table 2 shows the TSES Spanish version.

Job satisfaction was evaluated with the Mexican version of the Job Satisfaction composite scale (JSC) from TALIS (Organization for Economic Co-operation and Development [OECD], 2019b). Two subscales form this scale: Job satisfaction with work environment (JSWE; four items) and Job satisfaction with profession (JSP; four items). Items were coded using a four-point Likert scale ranging from 1 (strongly disagree) to 4 (strongly agree). The overall reliability of this TALIS scale used in Mexico was good ( $\alpha=0.79$ ); however, the internal consistency for its subscales displayed lower, though still acceptable values $\left(\omega_{J S W E}=0.75 ; \omega_{J S P}=0.64\right.$; Organization for Economic Cooperation and Development [OECD], 2019b).

\section{Data Analysis}

The collected data were analyzed using STATA 13. Prior to conducting the CFAs, the suitability of the sample data was tested. The Kaiser-Meyer-Olkin (KMO) test and Bartlett's test of sphericity were conducted to verify the adequacy of the data. Secondly, CFAs within the structural equation modeling framework (Brown and Moore, 2012) were applied to evaluate the structural validity evidence of the TSES. Two different models were generated so as to choose the one that better fit the data. First, a one-factor model was tested with all items loading on the same latent factor: teachers' self-efficacy. Then, a threefactor-correlated model, in which the three latent variables were those proposed by Tschannen-Moran and Woolfolk Hoy (2001): instructional strategies, classroom management, and student engagement.

To compute the quality of the CFAs, the goodness-of-fit of the examined models was tested through different fit indices: $x^{2} / d f$ ratio, where a ratio $\leq 3$ indicates a good fit (Byrne, 2004); root mean square error of approximation (RMSEA), where a value $\leq 0.08$ suggests a well-fitting model; standardized root mean square residual (SRMR), with acceptable values considered as $\leq 0.08$ (Hu and Bentler, 1999); and comparative fit index (CFI) and Tucker-Lewis index (TLI), where values $\geq 0.9$ demonstrate adequate fit (Bentler, 1990). The internal consistency of the obtained factors and the scale was verified by means of the Cronbach alpha's coefficient.

Criterion validity evidence of the TSES was assessed using Spearman's correlation analysis between self-efficacy and job satisfaction. This non-parametric correlation test was used since the data were previously checked for normality with the ShapiroWilk test and a non-normal distribution was found. Lastly, the

TABLE 2 | Spanish and original versions of the Teachers' Sense of Efficacy Scale (TSES).

\begin{tabular}{|c|c|c|c|c|c|c|c|c|c|c|c|c|c|c|c|c|c|}
\hline \multicolumn{9}{|c|}{ TSES Spanish version } & \multicolumn{9}{|c|}{ Original TSES (Tschannen-Moran and Woolfolk Hoy, 2001) } \\
\hline 1 & 2 & 3 & 4 & 5 & 6 & 7 & 8 & 9 & 1 & 2 & 3 & 4 & 5 & 6 & 7 & 8 & 9 \\
\hline $\begin{array}{l}\text { Nada/ En } \\
\text { absoluto }\end{array}$ & & y pc & & $\begin{array}{c}\text { Algo/En alguna } \\
\text { medida }\end{array}$ & & star & & $\begin{array}{l}\text { Mucho/ } \\
\text { Muy bien }\end{array}$ & $\begin{array}{l}\text { None } \\
\text { at all }\end{array}$ & & y lit & & $\begin{array}{c}\text { Some } \\
\text { degree }\end{array}$ & & te a & & $\begin{array}{c}\text { A great } \\
\text { deal }\end{array}$ \\
\hline
\end{tabular}

Eficacia para las estrategias instruccionales

5. ¿En qué medida puedes formular buenas preguntas a tus alumnos?

9. ¿En qué medida puedes emplear estrategias de evaluación variadas?

10. ¿En qué medida puedes proporcionar explicaciones o ejemplos alternativos cuando tus alumnos tienen dudas?

12. ¿Hasta qué punto puedes llevar a la práctica estrategias docentes alternativas en el aula?

Eficacia para el manejo de la clase

1. ¿Cuánto puedes hacer para controlar el comportamiento disruptivo en el aula? 3. ¿Cuánto puedes hacer para calmar a un alumno que se comporta de manera disruptiva o ruidosa?

6. ¿Cuánto puedes hacer para que tus alumnos cumplan las normas en el aula?

8. ¿Hasta qué punto puedes establecer un sistema de gestión del aula con cada grupo de alumnos?

Eficacia para la participación de los alumnos

2. ¿Cuánto puedes hacer para motivar a los alumnos que muestran un bajo interés en sus tareas escolares?

4. ¿Cuánto puedes hacer para ayudar a tus alumnos a valorar el aprendizaje?

7. ¿Cuánto puedes hacer para que tus alumnos se crean capaces de realizar con éxito sus tareas escolares?

11. ¿Cuánto puedes apoyar a las familias para que ayuden a sus hijos a ir bien en el colegio?
Efficacy for instructional strategies

To what extent can you craft good questions for your students?

To what extent can you use a variety of assessment strategies?

To what extent can you provide an alternative explanation or example when students are confused?

How well can you implement alternative strategies in your classroom?

Efficacy for classroom management

How much can you do to control disruptive behavior in classroom? How much can you do to calm a student who is disruptive or noisy?

How much can you do to get children to follow classroom rules? How well can you establish a classroom management system with each group of students?

Efficacy for student engagement

How much can you do to motivate students who show low interest in schoolwork?

How much can you do to help your students value learning?

How much can you do to get students to believe they can do well in schoolwork?

How much can you assist families in helping their children do well in school? 
Mann-Whitney $U$ test and the Kruskal-Wallis $H$ test were used to compare levels of self-efficacy regarding teachers' demographic variables: teachers' gender, subject taught, school level, years of teaching experience, and school model. If any test showed significant group differences $(p<0.05)$, a Mann-Whitney $U$ post hoc test was performed to compare two groups at a time (corrected for multiple comparisons by Dunn's Test). The estimated sizes of statistically significant effects are reported through Cohen's $r$.

\section{RESULTS}

\section{Construct Validity}

The Kaiser-Meyer-Olkin measure and Bartlett's test of sphericity demonstrated high strength in the relationships among items (KMO $\left.=0.915 ; \chi^{2}=1172.32, p<0.001\right)$, indicating appropriateness to perform a CFA. While the one-factor model showed a poor goodness-of-fit $\left(\chi^{2} / d f=3.53\right.$, RMSEA $=0.115$, SRMR $=0.059$, CFI $=0.881$, TLI $=0.854)$, the three-factor-correlated model showed a significant improvement $\left(\chi^{2} / d f=2.97, \mathrm{RMSEA}=0.102, \mathrm{SRMR}=0.053\right.$, CFI $=0.912$, TLI $=0.886$ ). However, RMSEA value was higher than recommended thresholds and TLI just below the cutoff score of 0.90 .

The factor structure of the three-factor-correlated model is shown in Figure 1. All items' factor loadings were higher than 0.30 and showed an excellent loading across their target factor, ranging between 0.59 and $0.86(p<0.001)$. Interfactor correlations were strong and positive, particularly the correlation between SE and CM (0.90).

Regarding reliability, the Cronbach's alpha coefficient of the Spanish TSES was 0.91, while the internal consistencies of its subscales were $\alpha_{I S}=0.78, \alpha_{C M}=0.85, \alpha_{S E}=0.82$. Thus, internal consistency of the overall TSES was good, while its subscales were acceptable to good. Table 3 presents the descriptive statistics of the Spanish TSES and its subscales, as well as the scores obtained in the original study regarding the short form scale (TschannenMoran and Woolfolk Hoy, 2001). The Spanish version of the TSES is presented in Supplementary Annex 1.

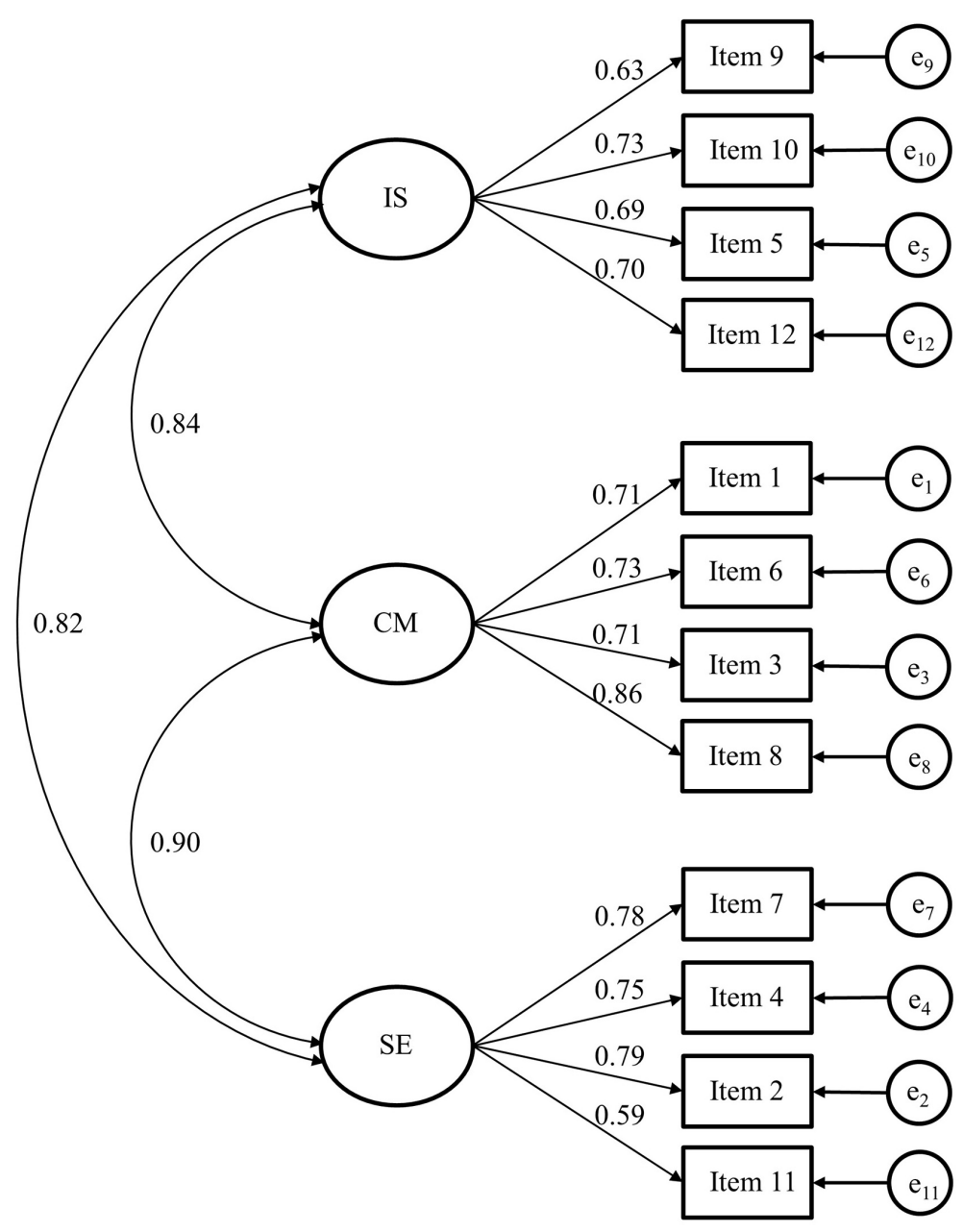

FIGURE 1 | Factor structure of the TSES (Spanish version). The number of the items corresponds to the order followed in the Spanish TSES (see Table 2). IS, efficacy for instructional strategies; CM, efficacy for classroom management; SE, efficacy for student engagement. 
TABLE 3 | Descriptive statistics and reliability for the Spanish and original versions of the TSES.

\begin{tabular}{|c|c|c|c|c|c|c|c|c|}
\hline & \multicolumn{5}{|c|}{ Spanish TSES } & \multicolumn{3}{|c|}{$\begin{array}{c}\text { Original TSES } \\
\text { (Tschannen-Moran and } \\
\text { Woolfolk Hoy, 2001) }\end{array}$} \\
\hline & Mean & SD & Median & IQR & $\alpha$ & Mean & SD & $\alpha$ \\
\hline TSES & 8.1 & 0.69 & 8.17 & 0.83 & 0.91 & 7.1 & 0.98 & 0.90 \\
\hline IS & 8.1 & 0.72 & 8.25 & 1 & 0.78 & 7.3 & 1.2 & 0.86 \\
\hline $\mathrm{CM}$ & 8.1 & 0.78 & 8.25 & 1 & 0.85 & 6.7 & 1.2 & 0.86 \\
\hline SE & 8 & 0.81 & 8 & 1.25 & 0.82 & 7.2 & 1.2 & 0.81 \\
\hline
\end{tabular}

Since the TSES scores were non-normally distributed in the Spanish TSES, the median has been reported as a central tendency measure and the IQR as a measure of statistical dispersion. TSES, Teachers' Sense of Efficacy Scale; IS, efficacy for instructional strategies; CM, efficacy for classroom management; SE, efficacy for student engagement; IQR, interquartile range; alpha, Cronbach' coefficient.

\section{Criterion Validity}

To verify the evidence of criterion validity for the TSES, correlation analyses were conducted between the variables of teacher self-efficacy and job satisfaction. Prior to these analyses, the Shapiro-Wilk test was used, and a significant deviation from normality was found ( $W=0.86, p<0.001$ ). Results from the non-parametric Spearman correlation test are shown in Table 4. Not all factors from the TSES were significantly correlated with the JSC scale and subscales. For example, while the JSWE subscale showed a weak correlation with each of the TSES factors, the JSP subscale did not correlate with any of the TSES factors.

In this study, the internal consistency for the JSC scale and subscales were good, with acceptable to high alpha and McDonald's omega coefficients $\left(\alpha_{J S C}=0.79 ; \omega_{J S W E}=0.84\right.$; $\left.\omega_{J S P}=0.63\right)$. The Spanish JSC scale is presented in Supplementary Annex 2.

\section{Group Differences in Teacher Self-Efficacy}

Due to the non-normal distribution of the data, the MannWhitney $U$ test was used to determine if there were significant differences between teachers' self-efficacy according to their gender and teaching subject (Spanish or mathematics). Results

TABLE 4 | Pair-wise correlations between the TSES and JSC.

\begin{tabular}{|c|c|c|c|c|c|c|c|}
\hline & TSES & IS & CM & SE & JSC & JSWE & JSP \\
\hline 1. TSES & 1 & & & & & & \\
\hline 2. IS & $0.87^{\star \star \star}$ & 1 & & & & & \\
\hline 3. $\mathrm{CM}$ & $0.91^{\star \star \star}$ & $0.70^{\star \star \star}$ & 1 & & & & \\
\hline 4. SE & $0.89^{\star \star \star}$ & $0.66^{\star \star \star}$ & $0.72^{\star \star \star}$ & 1 & & & \\
\hline 5. JSC & $0.19^{\star \star}$ & $0.16^{*}$ & $0.21^{\star \star}$ & 0.14 & 1 & & \\
\hline 6. JSWE & $0.25^{\star \star \star}$ & $0.21^{\star \star}$ & $0.26^{\star \star \star}$ & $0.19^{* \star}$ & $0.83^{\star \star \star}$ & 1 & \\
\hline 7. JSP & 0.09 & 0.09 & 0.09 & 0.06 & $0.86^{\star \star \star}$ & $0.49^{\star \star \star}$ & 1 \\
\hline
\end{tabular}

TSES, Teachers' Sense of Efficacy Scale; IS, efficacy for instructional strategies; $C M$, efficacy for classroom management; SE, efficacy for student engagement; JSC, Job satisfaction composite; JSWE, Job satisfaction with work environment; JSP, Job satisfaction with profession; ${ }^{*} p<0.05$; ${ }^{* *} p<0.01$; ${ }^{* * *} p<0.001$. revealed that the male participants had significantly greater levels of self-efficacy than their female colleagues $(z=2, p=0.045$, $r=0.15)$. However, no significant differences were found between female and male teachers regarding IS, CM, and SE subscales. Regarding differences according to the subject taught, Spanish and math teachers appeared to have similar ranks for teacher self-efficacy, as shown in Table 5.

Furthermore, we found teachers of seventh grade had the lowest medians for the different self-efficacy factors. Nonetheless, after conducting the Kruskal-Wallis $H$ tests, the only significant differences found among groups regarded SE scale: $H(4)=11.371, p=0.023$. Teachers in 7 th grade displayed lower SE levels than teachers in 4 th grade $(z=-1.96, p=0.025$, $r=0.14)$, 6th grade $(z=-1.93, p=0.027, r=0.14)$, and 8 th grade $(z=-2.36, p=0.01, r=0.17)$.

With respect to years of teaching experience, a positive correlation was found with teacher self-efficacy $(r=0.17$, $p=0.02)$, IS $(r=0.15, p=0.03)$, and CM $(r=0.16, p=0.02)$, whereas SE subscale did not correlate with years of teaching. Table 5 shows the medians and ranks regarding five established groups (1-5 years, 6-10 years, 11-15 years, 16-20 years, and $21+$ years; Dilekli and Tezci, 2020). After conducting the Kruskal-Wallis $H$ tests, the only significant differences found among groups regarded CM scale: $H(4)=10.615, p=0.031$. Teachers with 16-20 years of teaching experience presented significantly higher levels of CM than teachers with 6-10 years of experience $(z=-2.97, p=0.015, r=0.36)$.

Lastly, no significant differences were found regarding teacher self-efficacy based on employment at coeducational vs. singlesex schools. However, it is noteworthy that teachers employed at all-girls schools reported the lowest medians in all self-efficacy factors, whereas teachers at all-boys schools reported the highest values regarding self-efficacy (see Table 5).

\section{DISCUSSION}

This study aimed to examine the psychometric properties and obtain internal and external validity evidence supporting the use of the TSES in Spanish speakers while it is tested on a sample of Mexican teachers of private schools. Our results indicate that the Spanish TSES is a reliable instrument to measure and study teachers' self-efficacy beliefs in the Mexican context. Internal consistencies of the scale and its subscales were good, ranging from 0.78 to 0.91 , and were furthermore similar to those obtained in the original study: ranging from 0.81 to 0.90 (Tschannen-Moran and Woolfolk Hoy, 2001).

With reference to our first hypothesis, CFAs results indicate that the Spanish TSES has a three factor correlated structure, as originally proposed by Tschannen-Moran and Woolfolk Hoy (2001) for in-service teachers. As expected, the three factor correlated model showed better quality of fit than the one-factor model. However, RMSEA value (0.102) was higher than expected, and TLI value (0.886) was just below the critical threshold (0.08 and 0.9 , respectively). Similar results have been reported by Klassen et al. (2009), who found RMSEA values were higher than expected for Cypriot (0.105) and Korean (0.134) teachers. 
TABLE 5 | Medians and IQRs of teacher self-efficacy regarding participants' demographic variables.

\begin{tabular}{|c|c|c|c|c|c|c|c|}
\hline Variable & & $\mathbf{N}$ & TSES & IS & CM & SE & TSES comparison $p$-value \\
\hline \multirow[t]{2}{*}{ Gender } & Female & 120 & $8(0.92)$ & $8(1)$ & $8(1.13)$ & $8(1.25)$ & 0.046 \\
\hline & Male & 70 & $8.33(0.92)$ & $8.25(1)$ & $8.5(1)$ & $8.25(1)$ & \\
\hline \multirow[t]{2}{*}{ Subject } & Spanish & 91 & $8.17(0.91)$ & $8(0.75)$ & $8(1)$ & $8(1)$ & 0.067 \\
\hline & Mathematics & 99 & $8.17(0.83)$ & $8.25(1.25)$ & $8.25(1)$ & $8.25(1)$ & \\
\hline \multirow[t]{5}{*}{ School grade } & 4th grade & 45 & $8.17(0.91)$ & $8(1.25)$ & $8.25(1)$ & $8.25(1)$ & \\
\hline & 5 th grade & 39 & $8.17(1)$ & $8.25(1)$ & $8(1.25)$ & $8.25(1.25)$ & \\
\hline & 6th grade & 34 & $8.25(0.75)$ & $8.13(1)$ & $8.25(1)$ & $8.25(0.75)$ & 0.164 \\
\hline & 7th grade & 34 & $7.92(0.58)$ & $8(0.75)$ & $7.88(1)$ & $7.75(0.5)$ & \\
\hline & 8th grade & 38 & $8.25(1.08)$ & $8.38(1)$ & $8.38(1)$ & $8.25(1.25)$ & \\
\hline \multirow[t]{5}{*}{ Teaching experience } & $1-5$ years & 31 & $8(1)$ & $8(1)$ & $8(1)$ & $8.25(1)$ & \\
\hline & $6-10$ years & 35 & $7.83(0.92)$ & $8(1)$ & $8(1.25)$ & $7.75(1)$ & \\
\hline & $11-15$ years & 40 & $7.88(1.21)$ & $8.13(1.13)$ & $7.88(1.13)$ & $8.13(1.25)$ & 0.150 \\
\hline & $16-20$ years & 31 & $8.33(0.91)$ & $8.25(1.25)$ & $8.5(0.75)$ & $8.25(1.5)$ & \\
\hline & 21 or more & 53 & $8.25(0.58)$ & $8.25(0.75)$ & $8.25(0.75)$ & $8.25(0.75)$ & \\
\hline \multirow[t]{3}{*}{ School model } & Co-education & 93 & $8.17(0.75)$ & $8.25(1)$ & $8(1.25)$ & $8.25(1)$ & \\
\hline & Boys (single-sex) & 54 & $8.29(0.83)$ & $8.25(1)$ & $8.5(1)$ & $8.25(1)$ & 0.162 \\
\hline & Girls (single-sex) & 43 & $7.92(1.17)$ & $8(1)$ & $8(1)$ & $7.75(1)$ & \\
\hline
\end{tabular}

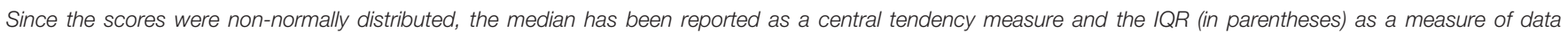

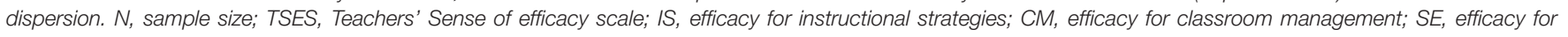
student engagement.

Likewise, Valls et al. (2020) obtained a high RMSEA (0.097) and a low TLI (0.87) with Swiss teachers. According to Ninković and Knežević-Florić (2018): "the differences obtained by fit indices could be attributed to different response styles, specificities of the social and cultural context, and school conditions" ( $p$. 84). Therefore, the RMSEA and TLI values indicated a certain discrepancy between the observed and expected values. It is worth noting that both indices are affected by sample size and may lead to false model rejections when the sample size is not adequate (Hu and Bentler, 1999). For this reason, it would be valuable that future studies conduct factor analyses of the TSES employing larger samples in order to assess the possible improvement of such goodness of fit indexes.

As to our second hypothesis regarding criterion validity evidence, the global construct of self-efficacy and its three factors showed positive and significant correlations with the JSC, as well as one of its subscales: job satisfaction with work environment. These results align with previous findings that suggest self-efficacy helps increase teacher job satisfaction in different educational contexts (Vieluf et al., 2013). In the present study, the classroom management factor displayed the highest correlations with work environment satisfaction, suggesting that when teachers perceived themselves as more capable of handling their class, they were more likely to feel satisfied with their job, and specifically, with their work environment. It is worth noting that the subscale of job satisfaction with profession did not correlate with teacher self-efficacy. These effects are manifested in a lower magnitude of the evidence of external validity between the TSES and job satisfaction in the sample of Mexican teachers. We must consider the negative asymmetric distribution of the scores of the job satisfaction with the profession subscale obtained in our sample, which in turn are manifested in low reliability. The latter increases the measurement error and is likely to attenuate the true correlations. Furthermore, although the TALIS 2018 report indicates a significant positive correlation between self-efficacy and job satisfaction, empirical evidence suggests that the final data corresponding to the job satisfaction survey was published with errors in the coding of its reversed items (Zakariya, 2020), which would call into question the objectivity of the published relations in the TALIS report, as well as it would require a new evaluation of its results. From a theoretical perspective, this may stem from the fact that satisfaction with the profession refers to more general aspects than capability beliefs, and rather seeks to determine whether or not a teacher would choose the teaching profession again if given the chance to go back in time and choose a career. Satisfaction with the work environment, however, focuses on a teacher's contentment regarding their current employment at their given school.

Further analyses were performed to examine group differences proposed in hypothesis three regarding Mexican teachers' selfefficacy. For this purpose, the literature typically uses parametric methods such as $t$-tests (for comparing two groups) and ANOVAs (for comparing more than two groups). However, after verifying that self-efficacy had a non-normal distribution, we used non-parametric tests that allowed a more valid data interpretation. Consequently, the Mann-Whitney $U$ test and Kruskal-Wallis $H$ test were used in this study. As some studies have previously found (Klassen and Chiu, 2010; Lumpe et al., 2012; Gulistan et al., 2017), male teachers appeared more confident in their capability to teach their students than female teachers. This difference is more clearly seen in 
the medians and ranks displayed by the teachers relative to the school model. In this way, as shown in Table 5, allboys schools with only male teachers presented higher levels of self-efficacy in all factors, whereas all-girls schools with only female teachers obtained the lowest levels of self-efficacy in all factors. Meanwhile, coeducational schools presented intermediate values, with $82.7 \%$ of these teachers being female and $17.2 \%$ male.

Concerning self-efficacy and school grade, seventh-grade teachers appeared to have the lowest self-efficacy levels. However, the only significant difference found concerned the student engagement subscale, suggesting that seventhgrade teachers perceived themselves as less capable of engaging students in the learning process. Similarly, Backhoff Escudero and Pérez-Morán (2015) found in the Mexican TALIS report that secondary education teachers presented lower levels of self-efficacy regarding student engagement than primary teachers. On the international stage, Fives and Buehl (2009) noted that elementary teachers presented higher levels of efficacy for student engagement than teachers at secondary schools, suggesting a need for targeted professional development programs for secondary teachers regarding student engagement.

The present study showed a curvilinear relationship between self-efficacy and years of teaching experience, similar to the one found by Klassen and Chiu (2010). Teachers with 1620 years of experience seem to have greater levels of selfefficacy than teachers with more or less years in the teaching profession. However, it is striking that teachers with 1-5 years in the teaching profession seem to have higher levels of selfefficacy than teachers with $6-10$ and $11-15$ years of teaching experience. These results led us to think that years of experience were not equally distributed in all school grades in this sample. To this respect, Table 6 illustrates how teaching experience is distributed across the different school grades (4th-8th grade). This table shows that the years of teaching experience in our sample were not evenly distributed regarding the school grade, which could be affecting the relationship between self-efficacy and teaching experience. I.e., most of the teachers with 15 years of experience are teaching in 4th grade, this may be the reason why beginner teachers in our sample appear to have higher levels of self-efficacy than middle experienced teachers. Future studies should include a more homogeneous distribution regarding teaching experience, so as to assess the effect of grade level taught on self-efficacy by controlling for teaching experience.

Lastly, it is worth nothing that the Mexican teachers who participated in this study showed relatively high levels of selfefficacy (as presented in Table 3). The means obtained in the original study ranged between 6.7 and 7.3 (Tschannen-Moran and Woolfolk Hoy, 2001) similar to those obtained in studies such as those of Ninković and Knežević-Florić (2018) and Valls et al. (2020); however, all means and medians from the present study were above 8 (on a scale rated from 1 to 9). These scores indicate that the majority of values obtained approach the upper limit of the scale used in its measurement, pointing to the possibility of a ceiling effect. A possible interpretation of this effect is that it could indicate a greater perception of selfefficacy beliefs in this sample of Mexican teachers in comparison with the rest of studies. Considering that the instrument has been tested in samples of different countries and that the response' options cover the same range values as the original scale (e.g., from $1=$ none to $9=$ a great deal), we do not believe the validity of the score interpretability to be limited. Specifically, we believe that the ceiling effect could be due to response bias which could in turn be produced by social desirability or a distorted perception of the self-efficacy domain of the participants. A recent study has indicated inconsistencies between personal judgments and teacher performance in a small sample of 24 teachers from Monterrey (Cocca et al., 2018), suggesting a distorted perception of their in-class performance, which could drive to lower quality of the teaching-learning process. The ceiling effect could be of particular concern during the evaluation of self-efficacy in specific samples and in longitudinal studies, as it would decrease the likelihood that the instrument will accurately measure this particular domain (Roberts et al., 2001; Kuusinen, 2016). To better understand the ceiling effect we found on this sample, it might be useful to check the TSES scores in a larger sample which include public teachers.

Finally, the higher values obtained on this sample may be due to varying reasons: the use of a self-report questionnaire that

TABLE 6 | Sample size and TSES scores regarding school grade and teaching experience.

\begin{tabular}{|c|c|c|c|c|c|c|c|}
\hline School grade & \multicolumn{5}{|c|}{ Teaching experience } & $\mathbf{N}$ & TSES \\
\hline 4th & 15 & 5 & 7 & 8 & 10 & 45 & $8.17(0.91)$ \\
\hline 5th & 2 & 8 & 8 & 5 & 16 & 39 & $8.17(1)$ \\
\hline 6th & 2 & 6 & 6 & 7 & 13 & 34 & $8.25(0.75)$ \\
\hline 7th & 6 & 12 & 8 & 3 & 5 & 34 & $7.92(0.58)$ \\
\hline TSES & $8(1)$ & $7.83(0.92)$ & $7.88(1.21)$ & $8.33(0.91)$ & $8.25(0.58)$ & & \\
\hline
\end{tabular}

Since the TSES scores were non-normally distributed, the median has been reported as a central tendency measure, and the IQR (in parentheses) as a measure of dispersion. N, sample size; TSES, Teachers' Sense of Efficacy Scale. 
reflects a social desirability bias (Organization for Economic Cooperation and Development [OECD], 2019a); the Likert scale, which ranges from 1 to 9 and may encourage overestimation (Valls et al., 2020), especially with Mexican teachers accustomed to scores ranging from 1 to 10 ; or the possible influence of cultural values like individualism and collectivism that have been detailed in previous studies (Vieluf et al., 2013; Fackler, 2018).

\section{Limitations and Future Directions}

Although our results are encouraging, some limitations should be addressed. First, the size of the sample was relatively small, however the obtained results were in line with previous studies. Second, in order to compare self-efficacy beliefs within teachers from the same school but different educational levels, participating teachers were all from private schools; thus, the findings of this research should be considered in the context of these characteristics. Further research should be conducted to study the psychometric properties of the Spanish TSES while considering the diversity of contexts within Mexico. Specifically, it would be useful to understand the self-efficacy beliefs of teachers at public schools, which account for about $90 \%$ of enrollment in primary and secondary education in Mexico (Instituto Nacional para la Evaluación de la Educación [INEE], 2019).

The aim of this study was to validate evidence associated with the Spanish-TSES while maintaining the characteristics of the original validation sample (e.g., primary and secondary) as well as its internal structure and response options. Considering the differences in the short-TSES scores found between our sample and samples of other countries, the moderate fit of our factor model and the characteristics of the current sample (small sample of private school teachers), we recommend that future studies include larger and general (public and private) samples and test for alternative factor models, and contemplate different scale responses (e.g., a 5-point Likert scale), so that the evidence shown in the present study could be accepted or rejected.

Future studies in Mexico and Latin America would be of great help so as to better understand how teacher self-efficacy behaves in these countries. Perhaps including a social desirability questionnaire or adapting the responses to a Likert scale from 1 to 5 , or 1 to 7 , may be useful to obtain more accurate results. Longitudinal and qualitative studies may also help to delve into the different nuances of teacher self-efficacy and how these beliefs are developed throughout the teaching career in the Spanishspeaking context.

Finally, since the scale has been revised by Spanish and Mexican experts who ensured the neutrality of the language used, researchers are furthermore encouraged to use this version of the TSES in different Spanish-speaking countries. The consistent use of a reliable validated scale for measuring teachers' self-efficacy would aid in promoting comparative studies on this topic. In this vein, further research should explore how cultural values in Spanish-speaking countries influence the ways in which teachers assess themselves as more or less capable of achieving proposed educational objectives.

\section{DATA AVAILABILITY STATEMENT}

The datasets presented in this article are not readily available because no consent was obtained from subjects to publicly share their pseudonymized data or to anonymize the data. Requests to access the datasets should be directed to FS-R (fsalas@alumni.unav.es).

\section{ETHICS STATEMENT}

Ethical approval was obtained by the Research Ethics Committee of the University of Navarra (Project ID: 2020.042). Written informed consent for participation was not required for this study in accordance with the national legislation and the institutional requirements.

\section{AUTHOR CONTRIBUTIONS}

FS-R, SL, and MM designed the study. FS-R contributed to the data collection, data analysis, and writing. SL contributed to the conceptualization and supervision of the study. MM contributed to the data analysis. All authors revised the draft, made substantial contributions, and approved the final manuscript.

\section{FUNDING}

This research was supported by a grant from the "Asociación de Amigos" of the University of Navarra.

\section{ACKNOWLEDGMENTS}

We would like to thank all the schools and teachers who participated in this study and Ruth Breeze for suggestions regarding the adaptation process of the scale.

\section{SUPPLEMENTARY MATERIAL}

The Supplementary Material for this article can be found online at: https://www.frontiersin.org/articles/10.3389/fpsyg. 2021.714145/full\#supplementary-material 


\section{REFERENCES}

Armor, D., Conroy-Oseguera, P., Cox, M., King, N., McDonnell, L., Pascal, A., et al. (1976). Analysis of the School Preferred Reading Programs in Selected Los Angeles Minority Schools. Santa Monica, CA: Rand.

Backhoff Escudero, E., and Pérez-Morán, J. C. (2015). Segundo Estudio Internacional sobre la Enseñanza y el Aprendizaje (TALIS 2013). Mexico City: Instituto Nacional para la Evaluación de la Educación.

Bandura, A. (1997). Self-Efficacy: The Exercise of Control. New York, NY: W. H. Freeman and Company.

Bentler, P. M. (1990). Quantitative methods in psychology: comparative fit indexes in structural models. Psychol. Bull. 107, 238-246. doi: 10.1037/0033-2909.107. 2.238

Berman, P., McLaughlin, M. W., Greenwood, P. W., McLaughlin, M. W., and Pincus, J. A. (1977). Federal Programs Supporting Educational Change: Factors Affecting Implementation and Continuation, Vol. VII. Santa Monica, CA: Rand.

Brown, T. A., and Moore, M. T. (2012). "Confirmatory factor analysis," in Handbook of Structural Equation Modeling, ed. R. H. Hoyle (New York, NY: The Guilford Press), 361-379.

Burgueño, R., Sicilia, A., Medina-Casaubón, J., Alcaraz-Ibañez, M., and Lirola, M. J. (2019). Psychometry of the teacher's sense of efficacy scale in Spanish teachers' education. J. Exp. Educ. 87, 89-100. doi: 10.1080/00220973.2018.1423542

Burić, I., and Kim, L. E. (2020). Teacher self-efficacy, instructional quality, and student motivational beliefs: an analysis using multilevel structural equation modeling. Learn. Instruct. 66:101302. doi: 10.1016/j.learninstruc.2019.101302

Burić, I., and Kim, L. E. (2021). Job satisfaction predicts teacher self-efficacy and the association is invariant: examinations using TALIS 2018 data and longitudinal Croatian data. Teach. Teach. Educ. 105:103406. doi: 10.1016/j.tate.2021. 103406

Burić, I., and Moè, A. (2020). What makes teachers enthusiastic: the interplay of positive affect, self-efficacy and job satisfaction. Teach. Teach. Educ. 89:103008. doi: $10.1016 /$ j.tate.2019.103008

Byrne, B. M. (2004). Testing for multigroup invariance using AMOS graphics: a road less traveled. Struct. Equ. Model. 11, 272-300. doi: 10.1207/ s15328007sem1102_8

Çapa, Y., Çakiroð̋lu, J., and Sarikaya, H. (2005). The developmeiit and validation of a Turkish version of the teacheis' sense of efficacy scale. Educ. Sci. 30, 74-81.

Caprara, G. V., Barbaranelli, C., Borgogni, L., and Steca, P. (2003). Efficacy beliefs as determinants of teachers' job satisfaction. J. Educ. Psychol. 95, 821-832. doi: 10.1037/0022-0663.95.4.821

Caprara, G. V., Barbaranelli, C., Steca, P., and Malone, P. S. (2006). Teachers' self-efficacy beliefs as determinants of job satisfaction and students' academic achievement: a study at the school level. J. Sch. Psychol. 44, 473-490. doi: 10.1016/j.jpp.2006.09.001

Casas Moreno, Y., and Blanco-Blanco, A. (2016). Una revisión de la investigación educativa sobre autoeficacia y teoría cognitivo social en hispanoamérica. Bordon 68, 27-47. doi: 10.13042/Bordon.2016.44637

Chesnut, S. R., and Burley, H. (2015). Self-efficacy as a predictor of commitment to the teaching profession: a meta-analysis. Educ. Res. Rev. 15, 1-16. doi: 10.1016/ j.edurev.2015.02.001

Cocca, M., Cocca, A., Alvarado Martínez, E., and Rodríguez Bulnes, M. G. (2018). Correlation between self-efficacy perception and teaching performance: the case of Mexican preschool and primary school teachers. Arab World English J. 9, 56-70. doi: 10.2139/ssrn.3150710

Covarrubias Apablaza, C. G., and Mendoza Lira, M. C. (2016). Adaptación y validación del cuestionario sentimiento de autoeficacia en una muestra de profesores chilenos. Univ. Psychol. 15, 97-108. doi: 10.11144/Javeriana.upsy152.avcs

Dilekli, Y., and Tezci, E. (2020). A cross-cultural study: teachers' self-efficacy beliefs for teaching thinking skills. Think. Skills Creativ. 35:100624. doi: 10.1016/j.tsc. 2019.100624

Dominguez-Lara, S., Fernández-Arata, M., Merino-Soto, C., Navarro-Loli, J., and Calderón-De la Cruz, G. (2019). Escala de autoeficacia docente: análisis estructural e invarianza de medición en docentes peruanos de escuelas públicas. Rev. Argen. Cienc. Comp. 11, 61-72.

Fackler, S. (2018). An International Perspective on Teacher's Self-Efficacy: Investigating Personal, Cultural, Structural and Environmental Factors. Oxford: University of Oxford.
Fackler, S., and Malmberg, L. E. (2016). Teachers' self-efficacy in 14 OECD countries: teacher, student group, school and leadership effects. Teach. Teach. Educ. 56, 185-195. doi: 10.1016/j.tate.2016.03.002

Fathi, J., Greenier, V., and Derakhshan, A. (2021). Self-efficacy, reflection, and burnout among iranian EFL Teachers: the mediating role of emotion regulation. Iran. J. Lang. Teach. Res. 9, 13-37. doi: 10.30466/ijltr.2021. 121043

Fives, H., and Buehl, M. M. (2009). Examining the factor structure of the teachers' sense of efficacy scale. J. Exp. Educ. 78, 118-134. doi: 10.1080/ 00220970903224461

Gulistan, M., Athar Hussain, M., and Mushtaq, M. (2017). Relationship between mathematics Teachers' self efficacy and Students' academic achievement at secondary level. Bull. Educ. Res. 39, 171-182.

Hajovsky, D. B., Oyen, K. A., Chesnut, S. R., and Curtin, S. J. (2020). Teacherstudent relationship quality and math achievement: the mediating role of teacher self-efficacy. Psychol. Sch. 57, 111-134. doi: 10.1002/pits.22322

Htang, L. K. (2018). Measurement of teacher sense of efficacy: a study with myanmar in-service teachers. J. Educ. Pract. 9, 39-48.

Hu, L., and Bentler, P. M. (1999). Cutoff criteria for fit indexes in covariance structure analysis: conventional criteria versus new alternatives. Struct. Equ. Modeling 6, 1-55. doi: 10.1080/10705519909540118

Instituto Nacional para la Evaluación de la Educación [INEE] (2019). La Educación Obligatoria. Informe 2019. In Instituto Nacional para la Evaluación de la Educación. Available online at: https://www.inee.edu.mx/wp-content/uploads/ 2019/04/P1I245.pdf (accessed December 9, 2020).

Khairani, A. Z., and Makara, K. A. (2020). Examining the factor structure of the teachers' sense of efficacy scale with malaysian samples of in-service and pre-service teachers. Pertanika J. Soc. Sci. Humanit. 28, 309-323.

Klassen, R. M., and Chiu, M. M. (2010). Effects on Teachers' self-efficacy and job satisfaction: teacher gender, years of experience, and job stress. J. Educ. Psychol. 102, 741-756. doi: 10.1037/a0019237

Klassen, R. M., Bong, M., Usher, E. L., Chong, W. H., Huan, V. S. Wong, I. Y. F., et al. (2009). Exploring the validity of a teachers' selfefficacy scale in five countries. Contemp. Educ. Psychol. 34, 67-76. doi: 10.1016/j.cedpsych.2008.08.001

Koniewski, M. (2019). The teacher self-efficacy scale (TSES) factorial structure evidence review and new evidence from polish-speaking samples. Eur. J. Psychol. Assess. 35, 900-912. doi: 10.1027/1015-5759/a000475

Künsting, J., Neuber, V., and Lipowsky, F. (2016). Teacher self-efficacy as a longterm predictor of instructional quality in the classroom. Eur. J. Psychol. Educ. 31, 299-322. doi: 10.1007/s10212-015-0272-7

Kuusinen, C. M. (2016). The Meaning and Measure of Teacher Self-Efficacy for Effective Classroom Teaching Practices. Ann Arbor, MI: The University of Michigan.

Lumpe, A., Czerniak, C., Haney, J., and Beltyukova, S. (2012). Beliefs about teaching science: the relationship between elementary teachers' participation in professional development and student achievement. Int. J. Sci. Educ. 34, 153-166. doi: 10.1080/09500693.2010.551222

Malinen, O. P., and Savolainen, H. (2016). The effect of perceived school climate and teacher efficacy in behavior management on job satisfaction and burnout: a longitudinal study. Teach. Teach. Educ. 60, 144-152. doi: 10.1016/j.tate.2016. 08.012

Ninković, S., and Knežević-Florić, O. (2018). Validation of the serbian version of the teachers' sense of efficacy scale (TSES). Zb. Inst. Pedagoska Istrazivanja 50, 72-92. doi: 10.2298/ZIPI1801072N

Organization for Economic Co-operation and Development [OECD] (2019a). TALIS 2018 Results: Teachers and School Leaders as Lifelong Learners, Vol. I. Paris: OECD Publishing. doi: 10.1787/1d0bc92a-en

Organization for Economic Co-operation and Development [OECD] (2019b). TALIS 2018 Technical Report. Available online at: https: //www.oecd.org/education/talis/TALIS_2018_Technical_Report.pdf (accessed December 9, 2020).

Perera, H. N., Calkins, C., and Part, R. (2019). Teacher self-efficacy profiles: determinants, outcomes, and generalizability across teaching level. Contemp. Educ. Psychol. 58, 186-203. doi: 10.1016/j.cedpsych.2019.02.006

Roberts, J. K., Henson, R. K., Tharp, B. Z., and Moreno, N. P. (2001). An examination of change in teacher self-efficacy beliefs in science education based on the duration of inservice activities. J. Sci. Teach. Educ. 12, 199-213. 
Ruan, J., Nie, Y., Hong, J., Monobe, G., Zheng, G., Kambara, H., et al. (2015). Cross-cultural validation of Teachers' sense of efficacy scale in three asian countries: test of measurement invariance. J. Psychoeduc. Assess. 33, 769-779. doi: $10.1177 / 0734282915574021$

Skaalvik, E. M., and Skaalvik, S. (2007). Dimensions of teacher self-efficacy and relations with strain factors, perceived collective teacher efficacy, and teacher burnout. J. Educ. Psychol. 99, 611-625. doi: 10.1037/0022-0663.99.3.611

Skaalvik, E. M., and Skaalvik, S. (2010). Teacher self-efficacy and teacher burnout: a study of relations. Teach. Teach. Educ. 26, 1059-1069. doi: 10.1016/j.tate.2009. 11.001

Skaalvik, E. M., and Skaalvik, S. (2016). Teacher stress and teacher self-efficacy as predictors of engagement, emotional exhaustion, and motivation to leave the teaching profession. Creat. Educ. 7, 1785-1799. doi: 10.4236/ce.2016.713182

Skaalvik, E. M., and Skaalvik, S. (2017). "Teacher stress and teacher self-efficacy: relations and consequences," in Educator Stress. Aligning Perspectives on Health, Safety and Well-Being, eds T. McIntyre, S. McIntyre, and D. Francis (Cham: Springer), 101-125. doi: 10.1007/978-3-319-53053-6_5

Tschannen-Moran, M., and Woolfolk Hoy, A. (2001). Teacher efficacy: capturing an elusive construct. Teach. Teach. Educ. 17, 783-805. doi: 10.1016/S0742051X(01)00036- 1

Tschannen-Moran, M., Woolfolk Hoy, A., and Hoy, W. K. (1998). Teacher efficacy: its meaning and measure. Rev. Educ. Res. 68, 202-248. doi: 10.3102/ 00346543068002202

Tsigilis, N., Grammatikopoulos, V., and Koustelios, A. (2007). Applicability of the Teachers' sense of efficacy scale to educators teaching innovative programs. Int. J. Educ. Manag. 21, 634-642. doi: 10.1108/09513540710822229

Tsigilis, N., Koustelios, A., and Grammatikopoulos, V. (2010). Psychometric properties of the Teachers' sense of efficacy scale within the greek educational context. J. Psychoeduc. Assess. 28, 153-162. doi: 10.1177/0734282909342532

Valls, M., Bonvin, P., and Benoit, V. (2020). Psychometric properties of the French version of the Teachers' sense of efficacy scale (TSES-12f). Eur. Rev. Appl. Psychol. 70:100551. doi: 10.1016/j.erap.2020.100551

Vieluf, S., Kunter, M., and Van de Vijver, F. J. R. (2013). Teacher self-efficacy in cross-national perspective. Teach. Teach. Educ. 35, 92-103. doi: 10.1016/j.tate. 2013.05.006

Wang, H., Hall, N. C., and Rahimi, S. (2015). Self-efficacy and causal attributions in teachers: effects on burnout, job satisfaction, illness, and quitting intentions. Teach. Teach. Educ. 47, 120-130. doi: 10.1016/j.tate.2014. 12.005

Wettstein, A., Ramseier, E., and Scherzinger, M. (2021). Class- and subject teachers' self-efficacy and emotional stability and students' perceptions of the teacher-student relationship, classroom management, and classroom disruptions. BMC Psychol. 9:103. doi: 10.1186/s40359-021-00606-6

Woolfolk Hoy, A., and Spero, R. B. (2005). Changes in teacher efficacy during the early years of teaching: a comparison of four measures. Teach. Teach. Educ. 21, 343-356. doi: 10.1016/j.tate.2005.01.007

Zakariya, Y. F. (2020). Investigating some construct validity threats to TALIS 2018 teacher job satisfaction scale: implications for social science researchers and practitioners. Social Sciences 9:38. doi: 10.3390/SOCSCI9040038

Zee, M., and Koomen, H. M. Y. (2016). Teacher self-efficacy and its effects on classroom processes, student academic adjustment, and teacher well-being: a synthesis of 40 years of research. Rev. Educ. Res. 86, 981-1015. doi: 10.3102/ 0034654315626801

Zee, M., and Koomen, H. M. Y. (2017). Similarities and dissimilarities between teachers' and students' relationship views in upper elementary school: the role of personal teacher and student attributes. J. Sch. Psychol. 64, 43-60. doi: 10. 1016/j.jsp.2017.04.007

Conflict of Interest: The authors declare that the research was conducted in the absence of any commercial or financial relationships that could be construed as a potential conflict of interest.

Publisher's Note: All claims expressed in this article are solely those of the authors and do not necessarily represent those of their affiliated organizations, or those of the publisher, the editors and the reviewers. Any product that may be evaluated in this article, or claim that may be made by its manufacturer, is not guaranteed or endorsed by the publisher.

Copyright (C) 2021 Salas-Rodríguez, Lara and Martínez. This is an open-access article distributed under the terms of the Creative Commons Attribution License (CC BY). The use, distribution or reproduction in other forums is permitted, provided the original author(s) and the copyright owner(s) are credited and that the original publication in this journal is cited, in accordance with accepted academic practice. No use, distribution or reproduction is permitted which does not comply with these terms. 